\title{
INFLUENCES IN A BIOLOGICALLY COMPLEX ADAPTIVE SYSTEM: ENVIRONMENTAL STRESS AFFECTS DENTAL DEVELOPMENT IN A GROUP OF ROMANO-BRITONS
}

\author{
A.H. BROOK ${ }^{1,2}$, K.S.B. $\mathrm{KOH}^{1}$ \& V.K.L. $\mathrm{TOH}^{1}$ \\ ${ }^{1}$ School of Dentistry, University of Adelaide, Australia. \\ ${ }^{2}$ Institute of Dentistry, Queen Mary University of London, England.
}

\begin{abstract}
The human dentition shows the general characteristics of a complex adaptive system. Interactions at a molecular level of genetic, epigenetic and environmental factors lead to the emergence of tooth germs. Subsequently differentiated specialised cells control mineralisation and then mature teeth emerge, showing marked variation. The mature dentition provides a record of developmental influences from its initiation at 6 weeks in utero to its completion at 20 years of age. It is, therefore, a valuable paradigm of general development.

The substantial collection of skeletal material of 200-400 AD Romano-Britons from Poundbury, Dorset, has been extensively studied, providing much evidence concerning lifestyle and medical conditions. In this study, we investigate further findings concerning dental development. The aims are to compare the findings with those for Modern Britons and to identify the effects of major factors known to affect the Romano-Britons in order to consider the possible synergism of these effects. The findings were that the patterning of the dentition, its sexual dimorphism and the types of developmental defects were similar to modern Britons. However, the RomanoBritons had more anomalies, generally smaller tooth crowns and roots, and more severe enamel defects. Thus, the Romano-Britons' dentition showed evidence of insults occurring at all stages of tooth development. These effects, occurring over a long period of time and affecting tissues with different genetic backgrounds, probably arise from ongoing major environmental insults known to be present in Poundbury. These insults have been identified as excess lead ingestion, poor nutrition and recurrent infections. We propose that these factors, acting synergistically, constituted marked environmental stress affecting development.

Keywords: complex adaptive system, dental development, Romano-British dentition
\end{abstract}

\section{INTRODUCTION}

1.1 The dentition as a complex adaptive system and model for general development

Investigating human development as a complex adaptive system has the potential both to enhance the understanding of the aetiology of development anomalies and to identify targets for their prevention. We have provided evidence that general and craniofacial developments are complex adaptive systems using dental development as a paradigm [1]. The detention is a valuable model as it is accessible and can be studied non-invasively. In contrast to many other physical and mental aspects of development, the teeth are durable hard tissues that can be accurately and repeatedly measured. The mature dentition provides a robust record of influences during development from its initiation at 6 weeks in utero to its completion at 20 years of age. There are extensive data concerning the genetic/epigenetic/environmental factors involved in dental development from animal and human studies. The genes, including homeobox genes, expressed in the early morphogenetic stages of dental development are common to the development of a number of other tissues. In the later stages of differentiation and mineralisation, different genes control the process and these processes act as a model for general mineralisation.

Dental development (Fig. 1) commences with bottom-up self-organisation as, at a molecular level, the genetic, epigenetic and environmental factors interact. These interactions occur within 
PROGRESSIVE DEVELOPMENT OF EACH TOOTH

$\underset{\begin{array}{c}\text { Initiation } \\ \text { (tooth number) }\end{array}}{\longrightarrow} \longrightarrow \underset{\begin{array}{c}\text { Differentiaton } \\ \text { (tooth tissues and } \\ \text { mineralisation) }\end{array}}{\longrightarrow} \longrightarrow$ Eruption

A. Genetic

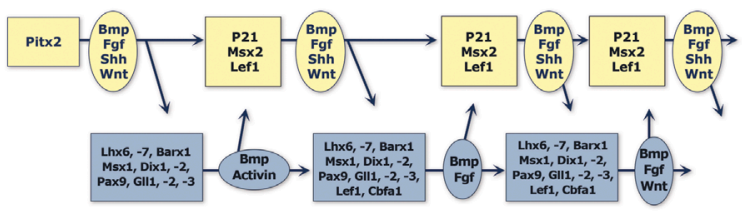

B. Cells/Tissues

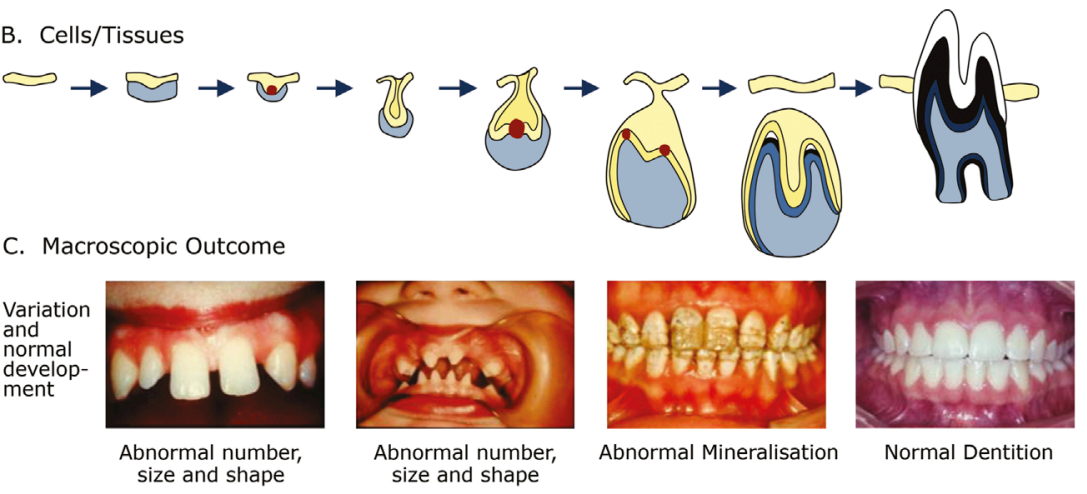

Figure 1: Overview of dental development: upper layer indicates ectoderm in (A) genes and (B) cells/tissues. The shaded lower layer in (A) and (B) indicates mesenchyme. Sections (A) and (B) are modified from http://bite-it.helsinki.fi/ (accessed 10 April 15). Figure reproduced with permission from Australian Dental Journal [1].

cells and their surrounding matrices, leading to the development and organisation of a specific number of higher level organs, the soft tissue tooth germs [1]. These emergent structures bear no resemblance to the precursor molecules. Within the tooth germs, cellular multiplication and apoptosis determine their size and shape at specific locations within the dental arches. Subsequent differentiation within the tooth germ provides specialised cells that control the subsequent mineralisation of the tooth germs. The mineralised mature teeth erupt and form a dynamic system that continues to adapt during function.

During development, cells multitask carrying out multiple functions: the enamel forming cells control the deposition of matrix and then its gradual removal as mineralisation proceeds. Self-adaptation occurs as epigenetic switches are used to turn genes on and off and control their expression; environmental factors are involved both directly and by causing epigenetic changes. There are critical phases or tipping points with thresholds determining further development. The performance of this complex adaptive system is improved by diversity with variation in outcome increasing the robustness of the system and allowing evolutionary development in response to environmental changes. Dental development also shows a series of network models; random network, threshold, scale-free, hierarchical and gene regulation network models, with subgraphs, motifs and motif clusters [1]. The erupted mature dentition continues to function as a complex adaptive system, with 
changes due to tooth wear and local environmental insults leading to adaptive responses that retain function.

\subsection{The Romano-British collection}

The substantial collection of skeletal material in the British Museum (Natural History) London from the excavation of the AD 200-400 cemetery in the Poundbury camp of the civitas capital of Durnovaria, Dorchester, Dorset has been extensively studied, providing much evidence concerning their lifestyle and the medical conditions they suffered [2]. The population was of native British origin and is thought to have lived as a close knit society with limited immigration for five or six generations. Age and sex determinations of the skeletal material were made by the staff of the British Museum using long bones, pelvic girdles and skulls. The people of Poundbury Camp probably had an agricultural lifestyle with cereal as the predominant element in the diet [2]. From an examination of 364 non-adults from Poundbury Camp, Lewis [3] provides evidence of high levels of rickets, scurvy and trauma in the children: iron deficiency and vitamin $\mathrm{C}$ and $\mathrm{D}$ deficiency are likely to have occurred together in the malnourished children. The presence of typical bony lesions is suggestive also of megaloblastic anaemia due to vitamin $B_{12}$ deficiency. In addition, gastrointestinal infections occurred [4]. The level of malnutrition in Poundbury Camp is marked and in some cases may be related to the maternal health during pregnancy [3]. The teeth and bones of the Poundbury population have been found to have a high lead content [5-8], with one potential source of this lead being the drinking vessels [2].

\section{AIMS}

The aims of this paper are to evaluate findings concerning dental development from this RomanoBritish population in comparison to results for Modern Britons in order to investigate the influence of the major environmental factors present in Poundbury over the duration of the full developmental process and to consider possible synergism of these effects.

\section{MATERIALS AND METHODS}

This investigation examined data for four outcomes of dental development: tooth number; crown size and shape; root size and shape and enamel structure. A total of 486 skulls had intact jaws and dentitions and were examined. Within this sample, subsamples were used for different aspects of the study according to the suitability of the material for scoring. For crown size, the subsample number was determined by statistical calculation. In each table, the sample size is given.

Visual examinations were made for tooth number and for enamel hypoplastic defects. Manual measurements using dial calipers were undertaken for mesio-distal and bucco-lingual crown size. Customised wooden wedges were constructed to position the skulls reproducibly and enable standardisation of six radiographs of each skull to cover the full dentition. Using these radiographs, the number of teeth formed in each individual, including unerupted teeth, was confirmed and the root number, size and shapes were scored. The criteria for diagnosis followed Brook [9] and Brook and Smith [10] and the hand measurement technique followed by Morrees et al. [11]. The same criteria were applied by the investigators in the studies of modern Britons used for comparison $[9,10,12]$. For each parameter, the levels of reproducibility of scoring were high.

\section{RESULTS}

The results are summarised in Tables 1-4. Table 1 indicates the findings for tooth number and visual size and shape; Table 2 for crown mesio-distal size measurements; Table 3 for root size and shape and Table 4 for enamel hypoplastic defects. 
Table 1: Prevalence for anomalies of tooth number, size and shape.

\begin{tabular}{lccc}
\hline & $\begin{array}{c}\text { Romano-British } \\
(\mathrm{n}=486), \%\end{array}$ & $\begin{array}{c}\text { Modern British } \\
(\mathrm{n}=1,115), \%\end{array}$ & Ref. \\
\hline Hypodontia of third molars & 39 & 12.7 & {$[13]$} \\
Hypodontia excl. third molars & 13 & 4.4 & {$[12]$} \\
Microdontia excl. third molars & 6.4 & 2.5 & {$[12]$} \\
Supernumerary teeth & 1.2 & 2.1 & {$[12]$} \\
\hline
\end{tabular}

Table 2: The mean mesio-distal diameters of each permanent tooth type and their standard deviations in 14- to 24-year-old Romano-Britons.

\begin{tabular}{lcccccc}
\hline Tooth & \multicolumn{2}{c}{ Male $(\mathrm{n}=30)$} & \multicolumn{2}{c}{ Female $(\mathrm{n}=30)$} & \multicolumn{2}{c}{ M:F differences } \\
\hline & Mean & SD & Mean & SD & $t$-Test & $p$-Value \\
\hline Maxilla & & & & & & \\
Central incisor & 8.42 & 0.30 & 7.87 & 0.34 & 6.6437 & $<0.0001$ \\
Lateral incisor & 6.57 & 0.40 & 6.43 & 0.37 & 1.4073 & 0.1647 \\
Canine & 7.60 & 0.32 & 7.28 & 0.24 & 4.3818 & $<0.0001$ \\
First premolar & 6.48 & 0.35 & 6.26 & 0.29 & 2.6511 & 0.0103 \\
Second premolar & 6.16 & 0.43 & 6.06 & 0.28 & 1.0674 & 0.2902 \\
First molar & 9.90 & 0.45 & 9.45 & 0.48 & 3.7461 & 0.0004 \\
Second molar & 9.40 & 0.59 & 9.10 & 0.60 & 1.9527 & 0.0557 \\
Third molar & 8.78 & 0.95 & 8.58 & 0.79 & 0.8866 & 0.3790 \\
Mandible & & & & & & \\
Central incisor & 5.11 & 0.25 & 4.96 & 0.25 & 2.3238 & 0.0237 \\
Lateral incisor & 5.77 & 0.32 & 5.53 & 0.37 & 2.6872 & 0.0094 \\
Canine & 6.68 & 0.31 & 6.30 & 0.21 & 5.5587 & $<0.0001$ \\
First premolar & 6.65 & 0.34 & 6.37 & 0.30 & 3.3823 & 0.0013 \\
Second premolar & 6.62 & 0.35 & 6.50 & 0.38 & 1.2722 & 0.2084 \\
First molar & 10.99 & 0.49 & 10.50 & 0.34 & 4.5000 & $<0.0001$ \\
Second molar & 10.48 & 0.37 & 10.16 & 0.55 & 2.6441 & 0.0105 \\
Third molar & 10.58 & 0.77 & 10.20 & 0.14 & 2.6594 & 0.0101 \\
\hline
\end{tabular}

These results show that in comparison with Modern Britons of European ancestry, the RomanoBritons exhibited;

1. The same types of dental development defects affecting tooth number, crown size and shape, root size and shape and enamel structure.

2. The same sexual dimorphism in tooth size and dental developmental defects with females having smaller teeth and a higher prevalence of hypodontia while males have larger teeth and a higher prevalence of supernumerary teeth.

3. A threefold greater prevalence of hypodontia (congenitally missing teeth) and microdontia (abnormally small teeth with reduced shape). 
Table 3: Prevalences in skulls and sex distributions of root anomalies.

\begin{tabular}{lccccc}
\hline & $\begin{array}{c}\text { No. of affected } \\
\text { males }\end{array}$ & Prevalence & $\begin{array}{c}\text { No. of affected } \\
\text { females }\end{array}$ & Prevalence & Sex ratio (M:F) \\
\hline $\begin{array}{l}\text { Three-rooted } \\
\text { mandibular first } \\
\text { molar }\end{array}$ & 3 & $\begin{array}{c}2.3 \% \\
(n=132)\end{array}$ & 3 & $\begin{array}{c}2.4 \% \\
(n=127)\end{array}$ & $1: 1(\mathrm{NS})$ \\
$\begin{array}{l}\text { Fused root (upper } \\
\text { and lower molar }\end{array}$ & 13 & $\begin{array}{c}8.5 \% \\
(n=153)\end{array}$ & 29 & $\begin{array}{c}19.5 \% \\
(n=149)\end{array}$ & $1: 2.2(p<0.02)$ \\
$\begin{array}{l}\text { teeth) } \\
\begin{array}{l}\text { Cuneiform root } \\
\text { (upper and lower }\end{array}\end{array}$ & 19 & $\begin{array}{c}12.4 \% \\
(n=153)\end{array}$ & 38 & $\begin{array}{c}25.5 \% \\
(n=149)\end{array}$ & $1: 2(p<0.01)$ \\
$\begin{array}{l}\text { molar teeth) } \\
\begin{array}{l}\text { Taurodonism } \\
\text { (lower molars) }\end{array}\end{array}$ & 48 & $\begin{array}{c}34.8 \% \\
(n=138)\end{array}$ & 31 & $\begin{array}{c}22.3 \% \\
(n=139)\end{array}$ & $1: 0.67(p<0.05)$ \\
\hline
\end{tabular}

Table 4: Prevalence of enamel hypoplastic defects [10].

\begin{tabular}{lcc}
\hline & $\begin{array}{c}\text { Romano-British } \\
(\mathrm{n}=178)(\%)\end{array}$ & $\begin{array}{c}\text { Modern British } \\
(\mathrm{n}=1,518)(\%)\end{array}$ \\
\hline Individual prevalence & 37.1 & 14.6 \\
Tooth prevalence & 8.0 & 1.7 \\
Percentage with $\geq 4$ teeth affected & 25.0 & 1.3 \\
Frequency of horizontal hypoplastic grooves & 29.8 & 1.8 \\
\hline
\end{tabular}

4. Smaller crown size.

5. Smaller root size with reduced shape. There were highly significant associations between fused and cuneiform roots $(p<0.001)$ and both were associated with hypodontia $(p<0.002$ and $p<0.05)$.

6. A threefold greater prevalence of enamel hypoplasia with the majority of affected individuals having four or more teeth involved.

\section{DISCUSSION}

Dental development has been shown to have the general characteristics of a complex adaptive system [1]. The findings of this investigation are that the dentition of these Romano-Britons showed the same general characteristics as that of Modern Britons and can therefore be considered as a complex adaptive system, developing from the interactions of genetic, epigenetic and environmental factors. However, there were substantial differences in the dimensions of teeth and the prevalence of anomalies between the findings for Romano-Britons and the Modern Britons.

This is modelled in Fig. 2 for tooth number, size and shape. This diagram is a development of the unifying aetiological model proposed by Brook [12] from the findings on Modern Britons and other Europeans. It is based on the normal distribution of tooth size, with separate curves for males and females reflecting the sexual dimorphism in tooth size. Thresholds are superimposed on these curves defining anomalies of tooth number, size and shape. The anomalies have the characteristics of quasicontinuous variables of multifactorial determination [12]. Supporting this model, a number of studies 


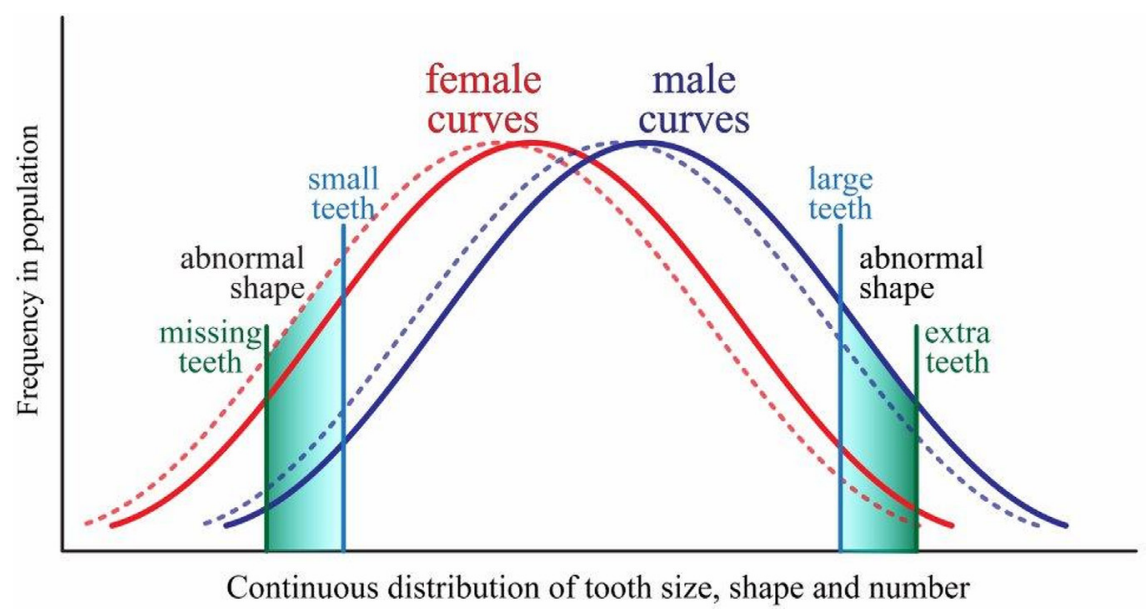

Figure 2: The unifying aetiological model of Brook [12] is developed here to include changes in tooth shape as well as tooth size. The solid lines are for Modern Britons and the dotted lines are for Romano-Britons. Figure reproduced with permission from Australian Dental Journal [14].

have shown that females have a higher prevalence of hypodontia and microdontia, whereas males have a higher prevalence of megadontia and supernumerary teeth [14]. In addition, there are statistically significant associations between hypodontia and smaller teeth and between supernumerary teeth and larger teeth [15-17]. Plotting the curves from the Romano-British data shows them to the left of the Modern British curve, reflecting the findings of higher frequency of hypodontia and microdontia, smaller crown and root size and lower frequency of supernumerary teeth for this Poundbury population.

The next consideration is what aetiological factors influenced this complex adaptive system to produce these differences (Fig. 3). During morphogenesis, the number, size and shape of the teeth are determined by a series of interactions between the genes in the epithelial and mesenchymal tissues (Fig. 1) [1]. The soft tissue tooth germs emerge from these reiterative interactions of the same genes at molecular and cellular levels. This explains the epidemiological and clinical findings of associations between anomalies of tooth number, size and shape, as in the Romano-Britons and Modern Britons that is modelled in Fig. 2.

However, in the subsequent differentiation stage within the soft tissue tooth germs that leads to mineralisation and the mature tooth, different genes are switched on and control the processes of matrix deposition and calcification [18]. In the Romano-Britons, the mature teeth show much greater levels of enamel defects than the Modern Britons (Table 4) and so they have a substantially higher level of development defects throughout the whole developmental period. It is unlikely that this is due to genetic mutations as these would need to be multiple, affecting the different genes involved in morphogenesis and in differentiation. Probably, the factor or factors causing the differences are generalised environmental agents present in the population throughout the whole period of dental development.

In Section 1 of this paper, evidence has been briefly reviewed for three areas of major, long-term environmental insults known to affect development in the Poundbury population: high levels of lead ingestion; poor general nutrition with identified vitamin and mineral deficiencies; and recurrent infections. Each of these environmental insults has been suggested as a cause of dental developmental defects in animals and human populations $[19,20]$ and has been identified as present in Poundbury [2]. Rather than having individual effects, they may have acted in summative or even synergistic ways to constitute major environmental stress throughout dental development in the Romano-British 


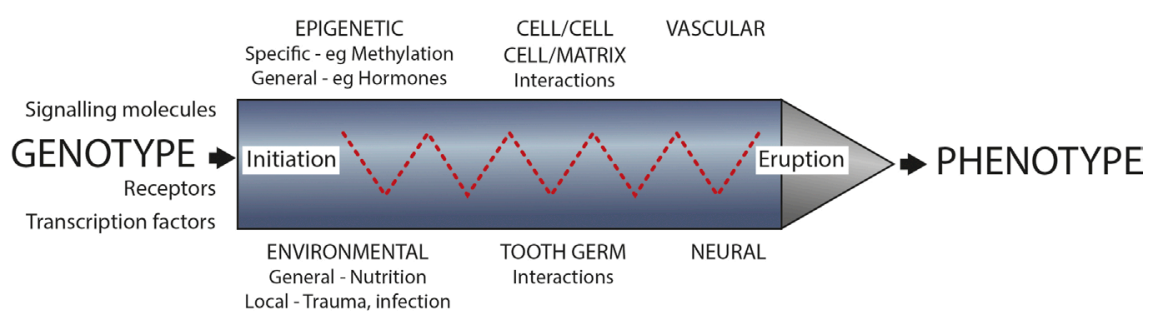

Major influences during development of tooth variations

Figure 3: The major influences on dental development from genotype to phenotype. In the RomanoBritons, three major environmental factors have been identified which may have part of their effect through epigenetic changes. Figure reproduced with permission from Australian Dental Journal [14].

population. While some of the action of these factors could be direct effects on the molecular and cellular processes of tooth development, they may also act indirectly through influences on the immune and endocrine systems and the production of epigenetic changes. If this is so, there could be transgenerational epigenetic changes affecting subsequent generations [21].

These findings have implications for modern populations suffering major environmental stress and emphasise the value of considering dental development both as a complex adaptive system and as a valuable model for evaluating factors affecting general development.

\section{ACKNOWLEDGEMENTS}

This investigation was supported by the Australian Dental Research Fund. We are grateful to Theya Molleson of the Natural History Museum, London, who provided not only access to material but also valuable advice and support. Contributions to the database used were made by a series of postgraduate students: L.K. Foo, C.A. Johns, M. Scheers, J.M. Smith and C.A. Underhill.

\section{REFERENCES}

[1] Brook, A.H., Brook O’Donnell, M., Hone, A., Hart, E., Hughes T.E., Smith, R.N. \& Townsend, G.C., General and craniofacial development are complex adaptive processes influenced by diversity. Australian Dental Journal, 59(1 Suppl), pp. 13-22, 2014. doi: http://dx.doi. org/10.1111/adj.12158

[2] Farwell, D.E. \& Molleston, T., Poundbury - Vol 2 - The cemeteries, Friary Press: Dorchester, UK, 1993.

[3] Lewis, M.E., Life and death in a civitas capital: metabolic disease and trauma in the children from late Roman Dorchester, Dorset. American Journal of Physical Anthropology, 142(3), pp. 405-416, 2010. doi: http://dx.doi.org/10.1002/ajpa.21239

[4] Walker, P.L., Bathurst, R.R., Richman, R., Gjerdrum, T. \& Andrushko, V.A., The causes of porotic hyperstosis and criba orbitalia: a reappraisal of the iron-deficiency-anaemia hypothesis. American Journal of Physical Anthropology, 139(2), pp. 109-125, 2009. doi: http://dx.doi. org/10.1002/ajpa.21031

[5] Waldron, H.A., Mackie, A. \& Townshend, A., The lead content of some Romano-British bones. Archaeometry, 18(2), pp. 221-227, 1976. doi: http://dx.doi.org/10.1111/j.1475-4754.1976.tb00165.x

[6] Waldron, H.A., Khera, A., Walker, G., Wibberley, G. \& Green, C.J., Lead concentration in bone and soil. Journal of the Archaeological Society, 6, pp. 295-298, 1979. doi: http://dx.doi. org/10.1016/0305-4403(79)90008-6 
[7] Stack, M.V. \& Whittaker, D.K., Lead, zinc and calcium concentrations in Romano-British teeth. Journal of Dental Research, 61(4), pp. 563, abstract 244, 1982.

[8] Whittaker, D.K \& Stack, M.V., The lead, cadmium and zinc content of some Romano-British teeth. Archaeometry, 26(1), pp. 37-42, 1984. doi: http://dx.doi.org/10.1111/j.1475-4754.1984.tb00315.x

[9] Brook, A.H., Variables and criteria in prevalence studies of dental anomalies of number, form and size. Community Dentistry and Oral Epidemiology, 3(6), pp. 288-293, 1975. doi: http:// dx.doi.org/10.1111/j.1600-0528.1975.tb00326.x

[10] Brook, A.H. \& Smith, J.M., The aetiology of developmental defects of enamel: a prevalence and family study in East London, U.K. Connective Tissue Research, 39(1-3), pp. 151-156, 1998. doi: http://dx.doi.org/10.3109/03008209809023921

[11] Morrees, C.F.A., Thomsen, S.O., Jenson, E. \& Yen, P.K-J., Mesiodistal crown diameters of deciduous and permanent teeth in individuals. Journal of Dental Research, 36(1), pp. 39-47, 1957. doi: http://dx.doi.org/10.1177/00220345570360011501

[12] Brook, A.H., A unifying aetiological explanation for anomalies of human tooth number and size. Archives of Oral Biology, 29(5), pp. 373-378, 1984. doi: http://dx.doi.org/10.1016/00039969(84)90163-8

[13] Shinn, D.L., Congenitally missing third molars in a British population. Journal of Dentistry, 4(1), pp. 42-44, 1975. doi: http://dx.doi.org/10.1016/0300-5712(76)90069-5

[14] Brook, A.H., Jernvall, J., Smith, R.N., Hughes. T.E. \& Townsend, G.C., The dentition: the outcomes of morphogenesis leading to variations of tooth number, size and shape. Australian Dental Journal, 59(1 Suppl), pp. 131-142, 2014. doi: http://dx.doi.org/10.1111/adj.12160

[15] Brook, A.H., Griffin, R.C., Smith, R.N., Townsend, G.C., Kaur, G., Davies, G.R. \& Fearne, J., Tooth size patterns in patients with hypodontia and supernumerary teeth. Archives of Oral Biology, 54(Suppl 1), pp. S63-S70, 2009. doi: http://dx.doi.org/10.1016/j.archoralbio.2008.05.016

[16] McKeown, H.F., Robinson, D.L., Elcock, C., Al-Sharood, M. \& Brook, A.H., Tooth dimensions in hypodontia patients, their unaffected relatives and control group, measured by a new image analysis system. European Journal of Orthodontics, 24(2), pp. 131-141, 2002. doi: http://dx.doi.org/10.1093/ejo/24.2.131

[17] Khalaf, K., Robinson, D.L., Elcock, C., Smith, R.N. \& Brook, A.H., Tooth size in patients with supernumerary teeth and a control group measured by an image analysis system. Archives of Oral Biology, 50(2), pp. 243-248, 2005. doi: http://dx.doi.org/10.1016/j.archoralbio.2004.09.013

[18] Brook, A.H., Multilevel complex interactions between genetic, epigenetic and environmental factors in the aetiology of anomalies of dental development. Archives of Oral Biology, 54(Suppl 1), pp. S3-S17, 2009. doi: http://dx.doi.org/10.1016/j.archoralbio.2009.09.005

[19] Small, B.W. \& Murray, M.J., Enamel opacities: prevalence, classifications and aetiological considerations. Journal of Dentistry, 6(1), pp. 33-42, 1978. doi: http://dx.doi.org/10.1016/03005712(78)90004-0

[20] Chen, H.S., Tsai, Y.C., Chen, K.K. \& Hsu K.J., Detrimental effects of maternal lead exposure during pregnancy and lactation on molar development in the young rat. Bulletin of Environmental Contamination and Toxicology, 89(2), pp. 240-244, 2012. doi: http://dx.doi. org/10.1007/s00128-012-0683-y

[21] Zambrano, E., Marinez-Samayoa, P.M., Bautista, C.J., Deás, M., Guillén, L., R odriguesGonzález,G.L., Guzmán, C., Larrea, F. \& Nathanielsz P.W., Sex differences in transgenerational alterations of growth and metabolism in progeny $\left(\mathrm{F}_{2}\right)$ of female offspring $\left(\mathrm{F}_{1}\right)$ of rats fed a low protein diet during pregnancy and lactation. Journal of Physiology, 566(1), pp. 225-236, 2005. doi: http://dx.doi.org/10.1113/jphysiol.2005.086462 